\title{
Construct Validity of Mathematical Creativity Instrument: First-Order and Second-Order Confirmatory Factor Analysis
}

\author{
M. Zainudin \\ University, Indonesia, m.zainudin2016@student.uny.ac.id \\ Bambang Subali \\ Yogyakarta State University, Indonesia, bambangsubali@uny.ac.id
}

Post Graduate Program of Educational Research and Evaluation, Yogyakarta State

Jailani

Yogyakarta State University, Indonesia, jailani@uny.ac.id

Mathematical creativity instrument is a tool to assess students' creative thinking skills in solving mathematical problems. Mathematical creativity has a pivotal role in improving the quality of life, solving problems, making a change, and increasing the efficiency and effectiveness of a system. Unfortunately, there is a gap in the assessment of mathematical creativity in Indonesia because the instrument used is merely confirm teachers' explanation through mathematical problem which focuses on measuring students' knowledge. Therefore, it is necessary to prove the construct validity of the items in the instrument of mathematical creativity assessment. Based on the concept, there are 3 aspects used in creating mathematical creativity instruments, i.e. fluency, flexibility, and originality. This study aimed at examining the construct validity of the instrument. This study used a design and development model. The data were obtained from testing 313 junior high school students in Indonesia. The data were analyzed using Confirmatory Factor Analysis (CFA), using Lisrel 8.80 software through the first-order and the second-order stages. The results show that of all items, totally 15 items, are valid or uni-dimensional with TValue at the value of the loading factor $>1.96$. This finding proves that unidimensional data parameters can measure the constructs of mathematical creativity and have a significant effect.

Keywords: construct validity, mathematical creativity, first-order confirmatory factor analysis, second-order confirmatory factor analysis

\section{INTRODUCTION}

Highly creative human resources in STEM (Science, Technology, Engineering, and Mathematics) are important for national welfare (National Academies of Science, 2007:

Citation: Zainudin, M., Subali, B., \& Jailani. (2019). Construct Validity of Mathematical Creativity Instrument: First-Order and Second-Order Confirmatory Factor Analysis. International Journal of Instruction, 12(3), 595-614. https://doi.org/10.29333/iji.2019.12336a 
91-110). The members of the National Academy of Science developed a list of recommended actions needed to ensure that the United States can continue to compete globally. The main recommendation is to improve American talent by improving Mathematics and science education. Florida \& Cities (2012), state that creativity is a part of economic development in the United States. Creativity, knowledge, and skill can help individual to have innovative ideas which can help the state to achieve its goals (Hana, 2013).

The role of creativity in national welfare is in line with the importance of creativity in the world of work. One's creativity needs to be developed because this ability is one of the desired aspects by the world of work (Career Center Maine Department of Labor, 2004). A person with high creativity can solve a problem of work through various ways. Jaarsveld \& Lachmann (2017) state that one of the indicators of creativity is the ability of solving problems through various ways, therefore, the individual who has a high creativity can propose various alternative of problem solving.

The development of one's creativity is also a part of learning activities at school. Heppell, Chapman, Millwood, Constable, \& Furness (2004) state that education is not enough to only provide students access to information, but is required to develop creativity to face the rapid and complex development of the world of work.

Nadjafikhah, Yaftian, \& Bakhshalizadeh (2012) state that developing students' creativity in schools can be done through solving mathematical problems which are then referred to as mathematical creativity. Students can develop creativity through constructing new ideas so that mathematical problems that can be solved with new answers that are not commonly used by most students. This is in line with the statement of Sriraman (2012) that one can develop mathematical creativity through solving mathematical problems with new solutions.

Kiesswetter (1983) states that based on his experience, flexible thinking ability which is one of the components of creativity is the most important that individuals must possess in solving mathematical problems. This opinion confirms that creativity can also be developed through mathematical solutions. Haylock (1997) states that creativity in mathematics must be defined in the area of creativity and mathematics. According to him, mathematical creativity has the same meaning as creativity in school mathematics.

The development of students' mathematical creativity in schools requires an instrument of creativity. Some studies on instruments of creativity in mathematics had also been carried out by Cho (2003); Cho (2006); Kim, Cho, \& Ahn, (2003); Urban (2003); Lin \& Cho (2011); Mann (2005); Lee, Hwang, \& Seo (2003) and Israel Livne \& Milgram (2006). An instrument which is developed by H. Kim et al., (2003); Lee, Hwang, \& Seo (2003) and Israel Livne \& Milgram (2006) measure three aspects of creativity, i.e. fluency, flexibility, and novelty. Fluency reflects the number of correct answers; flexibility counts the number of categories of correct answers, and originality means the rarity of each correct answer. Fluency is related to speed, accuracy, and effectiveness in providing solutions for 6 or 7 minutes per problem encountered (Schoenfeld, 2015). Flexibility refers to the number of different types or categories of appropriate solutions 
and originality refers to the originality of the results of each answer (Schoevers, Kroesbergen, \& Kattou, 2018).

The instruments for measuring students' mathematical creativity had been developed in Korea (H. Kim et al., 2003; Lee, Hwang, \& Seo, 2003) and Israel (Livne \& Milgram, 2006), but these instruments have not been used internationally, either because it is not published in English or because the use of these instruments takes time. The instruments of students' mathematical creativity have also been investigated by Lin \& Cho (2011), but the sample involved was elementary school students who $14.4 \%$ of them were identified as gifted students. The criteria of the students involved in the study were they must come from complete parents, born in Taiwan and speak either Chinese or Taiwanese at home. The possible threat to internal validity in this study is the certain sample of participants involved so that the construct under this study is not necessarily appropriate if applied in Indonesia.

The instruments for measuring students' mathematical creativity had been developed in Korea (H. Kim et al., 2003; Lee, Hwang, \& Seo, 2003) and Israel (Livne \& Milgram, 2006), but these instruments have not been used internationally, either because it is not published in English or because the use of these instruments takes time, so it can be said that there is no standardized instrument that can be used as a reference. The scarcity of the standardized reference requires analysis of the data obtained from the test results with these instruments analyzed by Item Response Theory (IRT) to obtain more accurate data information. The scarcity of the standardized mathematical creativity test instrument also requires that the assessments can be carried out through norms-based reference. The norms-based reference assessment uses a reference between values in the group being tested. Dealing with this, it is needed a study dealing with a test that can describe students' mathematical creativity efficiently with a valid instrument based on analysis with IRT and can be used in assessing students' mathematical creativity based on norms. Therefore, it is also needed a study on the instruments of mathematical creativity that can be used by junior high schools in Indonesia.

\section{CONTEXT AND LITERATURE REVIEW}

Some experts define creativity from various points of view, including Nadjafikhah \& Yaftian (2013) who state that creativity is the result of one's ability to generate new ideas. These new ideas are related to ideas that have never existed before. A new idea produced by a person can also come from the results of the construction of several ideas that already exist so it produces ideas that are more complex than before.

Grieshober (2004) defines creativity as a result of the process of constructing ideas that emphasize the aspects of fluency, flexibility, and originality. The same thing was stated by McGregor (2007) that creativity is the result of thinking that leads to the acquisition of new insights or new ideas in solving a problem that shows fluency, flexibility, and originality in thinking. Meanwhile, according to Martin (2009), creativity is the result of one's ability to be fluent, flexible and original to generate new ideas or ways of solving problems. 
Dogan (2011) states that creativity is the skill to express, shape, create and discover new or original thoughts, or to produce new products in a fluent, flexible and original way. One of the main indicators in creativity is new results. The new results in creativity are alternative solutions that have not been taught by teachers or not found in existing books.

Based on some experts' opinions above, it is concluded that creativity is the result of the process of constructing ideas to produce new products in a fluent, flexible and original way that describes a person's skills.

Livne (2008) explains that mathematical creativity, in a simple way, refers to the ability to produce varied solutions that are new to open mathematical problems. The more detailed explanation is stated by Torrance (1990) that the domain of mathematical creativity is fluency, flexibility, and originality. Furthermore, Kattou, Kontoyianni, PittaPantazi, \& Christou (2011) state that based on the study on predicting mathematical creativity concludes that students' mathematical creativity can be described from the solution of fluency, flexibility, and originality domains, while other domains related to mathematical creativity but not significant is spatial ability, quantitative ability, qualitative ability, causal ability, and inductive or deductive ability.

One of the most important things in evaluating mathematical creativity instrument is the validity of all items to measure mathematical creativity in Indonesia. Dealing with this, the proof of construct validity is needed for all instrument items. Based on this, a unidimensional measurement of each indicator is carried out to see the biggest contribution that creates the latent variable using CFA (Confirmatory Factor Analysis).

This study is different from the previous studies conducted in Indonesia because those previous studies were more focused on studying about the effectiveness of learning on improving mathematical creativity (Makmur, 2015) and the description of the profiles of students' mathematical creativity (Novitasari, Rahman, \& Alimuddin, 2015), and the analysis of the relationship between students' mathematical creativity (Rahman, 2012). This study aims to prove empirically: 1) whether or not all items in each dimension measure constructs, where all items in each dimension match one-factor model, 2) whether or not all items in each dimension have a significant effect.

Theoretically, this study can be used as a reference for the development of mathematical creativity instruments. Practically, this study can be used to make improvements that are able to measure students' mathematical creativity.

\section{METHOD}

This study belongs to developmental research, to obtain a construct of dimensions or factors in relation to mathematical creativity, especially junior high school students in Bojonegoro, East Java, Indonesia.

\section{Design and Approach}

This study used design dan development (D \& D) model, consisting of a) specification of the instrument, b) reviewing instruments that once existed, c) definition of constructs 
and definitions of concepts, d) creating a component specification of the instrument construct, e) the development of the ending concept definition for each construct, $\mathrm{f}$ ) building an operational definition, g) choosing a scale and deciding the indicator, 8) loading and pairing items to construct, h) reviewing the item of instruments (Expert Validity: Focus Group Discussion (FGD)), i) Limited testing-Readability test: senior high school, j) Instrument Revision-Initial product, k) making the last assessment instrument, j) collecting the data from trial test; k) analyzing the trial result with confirmatory factor analysis (CFA).

\section{Subjects}

The population of this study was the junior high school students, referring to the data from the East Java Province Education Office in 2017. The population consisted of 18,722 junior high school students. The sampling technique in this study used a proportional random sampling technique (Cohran, 2010: 85). The researchers established a sample of 313 students, consisting of 87 students from high-category schools, 110 students from medium-category schools, and 116 students from lowcategory schools based on the national examination scores for mathematics subjects in 2017. The sample size in the CFA analysis was determined by the number of observed variables or items. For the sample size, it is recommended to use the estimated Maximum Likelihood (ML) at 100-200 (Hair, Black, Babin, \& Anderson, 2006).

\section{Data Collection}

The data in this study were collected using questionnaire and test methods. The questionnaire method in this study was used to collect validator's assessment data on the mathematical creativity test instrument for items improvement. The test method was used to collect data on students' mathematical creativity as empirical evidence for determining the quality of the instrument and the construct of the instrument of mathematical creativity used in junior high schools in Indonesia. The general profile of the trial participants was junior high school students (average age 12-15 years old). The instrument consists of 15 items with outlines as in Table 1. 
Table 1

The Outlines of Mathematical Creativity Instrument

\begin{tabular}{|c|c|c|}
\hline Dimension & Indicator & Indicator of questions \\
\hline Fluency & $\begin{array}{l}\text { the ability } \\
\text { to produce } \\
\text { many } \\
\text { solutions/id } \\
\text { eas to a } \\
\text { problem }\end{array}$ & $\begin{array}{l}\text { 1. Identifying variuous measurements of cuboid area with wrapping paper. } \\
\text { 2. Designing various measurements of cuboid which has a certain area. } \\
\text { 3. Designing various measurements of prism which has the same volume with } \\
\text { the cube. } \\
\text { 4. Designing various measurements of side of prism which has a certain area. } \\
\text { 5. Designing various measurements of height of pyramid which has a certain } \\
\text { area of pedestal and volume. }\end{array}$ \\
\hline Flexibility & $\begin{array}{l}\text { the ability } \\
\text { to generate } \\
\text { different } \\
\text { types of } \\
\text { solutions/id } \\
\text { eas }\end{array}$ & $\begin{array}{l}\text { 1. Solving the problems of cube area using various ways. } \\
\text { 2. Solving the problems of cuboid area using various ways. } \\
\text { 3. Solving the problems of added volume from a cube which has a certain } \\
\text { volume using various ways. } \\
\text { 4. Solving the problems of prism volume based on the pattern of cuboid. } \\
\text { 5. Solving the problems of form of prism fulfilled with water and has a hole } \\
\text { with certain capacity of water discharge. }\end{array}$ \\
\hline Originality & $\begin{array}{l}\text { the ability } \\
\text { to generate } \\
\text { rare and } \\
\text { uncommon } \\
\text { solution/ide } \\
\text { as }\end{array}$ & $\begin{array}{l}\text { 1. Solving the problems of the number of small cubes which could fit into a } \\
\text { certain measurement of cuboid. } \\
\text { 2. Solving the problems of a cuboid gift area which has the same area with } \\
\text { cube with certain measurement. } \\
\text { 3. Solving the problems of the area of triangular prism which has certain area. } \\
\text { 4. Solving the problems of how much money is needed to buy snack inserted } \\
\text { into cuboid with certain measurement using various ways. } \\
\text { 5. Solving the problems of volume of pyramid in the cube with certain } \\
\text { measurement using various ways. }\end{array}$ \\
\hline
\end{tabular}

Source: Kind \& Kind (2007)

The response scoring based on the indicators of fluency, flexibility, and originality in this study was made into polytomous scaling. The scoring on the fluency domain is as follows.

Table 2

Scoring Rubrics in the Fluency Domain

\begin{tabular}{ll}
\hline Score & Criteria \\
\hline 1 & $\begin{array}{l}\text { At least one correct answer or the number of correct answers does not reach the } \\
\text { minimum set }\end{array}$ \\
2 & The number of correct answers reaches the minimum set \\
3 & The number of correct answers exceeds the minimum set \\
\hline
\end{tabular}

Table 3

Scoring Rubrics in the Flexibility Domain

\begin{tabular}{ll}
\hline Score & Criteria \\
\hline 1 & At least one way in giving the correct answer or the number of ways in giving the correct \\
& answer does not reach the minimum set \\
2 & The number of ways in giving the correct answer reaches the minimum limit set \\
3 & The number of ways in giving the correct answer exceeds the minimum set \\
\hline
\end{tabular}

The scoring against the respondents' responses for originality domain follows the recommended scoring technique by Diakidoy \& Constantinou (2001, p.38) i.e. the response given by less than $5 \%$ of the respondents gets the score of 3 , less than $15 \%$ of 
respondents get the score of 2 and less than $50 \%$ of respondents get the score of 1 . The explanation of the number of items of pedagogical competence can be seen in Fig. 1.

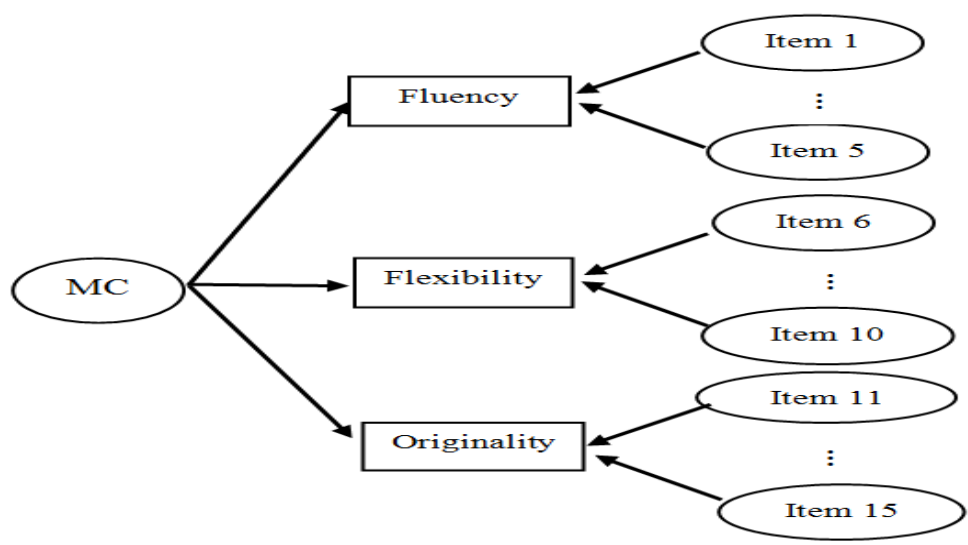

Figure 1

The Number of Items in Mathematical Creativity Test

\section{Data Analysis}

The data analysis to test the construct validity of mathematical creativity instruments has three dimensions: fluency (FLU), flexibility (FLE), and originality (ORI), in which each dimension has their own indicators representing FLU, FLE, and ORI. The researchers used a factor analysis approach such as confirmatory factor analysis (CFA) to analyze it.

CFA analysis was chosen because the theoretical model can be tested and the relationship among factors can also be observed. Based on CFA analysis, it can be known which analysis should be used in measuring mathematical creativity. For this reason, uni-dimensional measurements were carried out for each indicator: FLU, FLE and ORI on mathematical creativity using the First Order Confirmatory Factor Analysis method, which is a latent variable analysis that is measured based on several indicators that can be directly measured.

The data in this study were analyzed using Confirmatory Factor Analysis (CFA) consisting of first-order and second order with the software of Lisrel 8.80 was used. The evaluation criteria for the model fit were by p-value on Chi-square 2 and the Root Mean Square Error of Approximation (RMSEA). (Joreskog \& Sorbom, 2003: 128) explain that the model was declared fit if the p-value was greater than Chi-square 2; was not significant if p-value $>0.05$, meaning there is no significant difference between the model with the data. The evaluation model with the RMSEA was expected to show the RMSEA value of $\leq 0,05$ for the model considered as close to or the RMSEA value of $\leq 0,08$ for a model declared as a good fit model. Furthermore, the fit instrument construct was used to map the level of mathematical creativity, referring to the score of mathematical creativity (X): $\mathrm{X}<\mu-1 \sigma$ (low category), $\mu-1 \sigma \quad X<\mu+1 \sigma \quad$ (medium category), and $\mu+1 \sigma \leq X$ (high category). 


\section{FINDINGS}

Confirmatory Factor Analysis (CFA) is a method of factor analysis used when researchers have knowledge of the structure of a latent factor. The structure is obtained based on theoretical studies, the results of research on the relationship between variables observed with latent variables. CFA is divided into CFA First-Order and CFA SecondOrder.

The results of CFA analysis by using the First-and Second-Order Confirmatory Factor Analysis method in this study were to prove all items in each latent variable such as FLU, FLE and ORI measure the construct of mathematical creativity and each item in each dimension match to one factor model and also with each item in each dimension gives a significant influence.

\section{The First Order Confirmatory Factor Analysis}

In First-Order CFA, a latent variable is measured based on several indicators that can be measured directly. Figure 2 shows the testing of the First Order CFA model which consists of one latent variable with $p$ indicator.

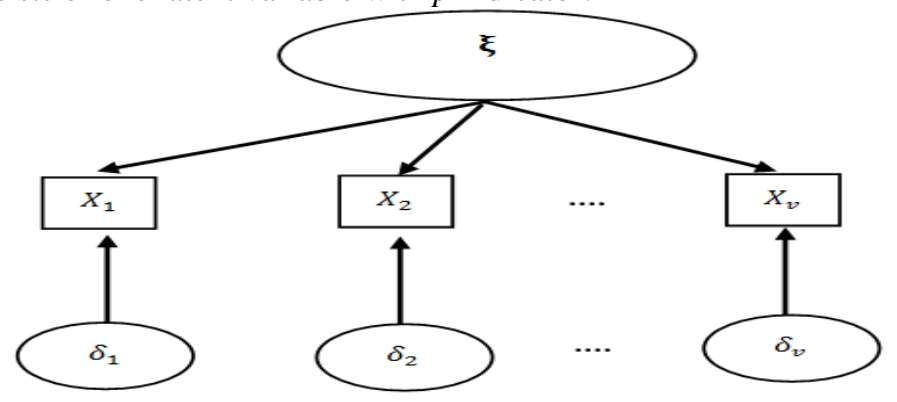

$\mathrm{x}=\wedge \mathrm{x}+\delta$

Information:

$\mathrm{x}=\wedge \mathrm{x}+\delta$

Figure 2

First-order Confirmatory Factor Analysis Model

\section{The Latent Variable of Fluency}

This latent variable was measured based on 2 indicators, i.e. 1) students solve problems with various interpretations, solution, methods or answers (FLU1), 2) students are able to express many ideas about a problem in 5 minutes (FLU2). The first indicator (FLU1) was developed into 3 items (FLU1.1-FLU1.3), while indicator 2 (FLU2) was developed into 2 items (FLU2.4-FLU2.5). For that reason, it is proven that all 5 items have unidimensional characteristics, which means only measuring the latent variable of fluency. CFA analysis results of fluency variables by using the First Order Confirmatory Factor Analysis is shown in Figure 3 below. 


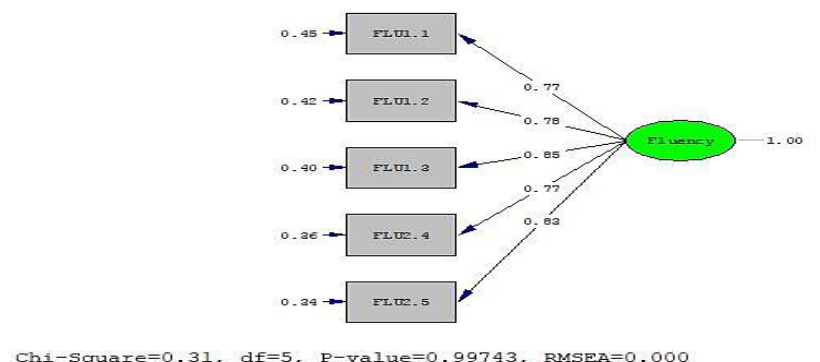

Figure 3

Confirmatory Factor Analysis of Fluency Variable

Based on the CFA analysis using the First Order Confirmatory Factor Analysis, the results obtained the fit model because Chi-Square $=0.31$, df $=5, \mathrm{P}$-value $=0.99743$, RMSEA $=0,000$. This means that by using one factor (uni-dimensional) all items only measure one single factor, fluency, as presented in Figure 3.

The proof of each item contributing significantly to the fluency variable was done by checking the T-Value of each loading factor coefficient as in Table 4 below.

Table 4

Loading Factor for FLU Items

\begin{tabular}{lllll}
\hline Item & Coefficient & Standard error & T-Value $(>1,96)$ & Criteria \\
\hline FLU1.1 & 0,77 & 0,45 & 15,03 & Significant \\
FLU1.2 & 0,78 & 0,42 & 15,04 & Significant \\
FLU1.3 & 0,85 & 0,40 & 16,50 & Significant \\
FLU2.4 & 0,77 & 0,36 & 16,15 & Significant \\
FLU2.5 & 0,83 & 0,34 & 16,93 & Significant \\
\hline
\end{tabular}

Table 4 shows the loading factor of all items that have a positive coefficient value and each item has T-Value> 1.96 so that it is concluded to be significant. It means that there is no item omitted from the model indicator. Furthermore, the value of the variantcovariance matrix was tested by measuring the suitability of the Goodness of Fit model, as shown in Table 5.

Table 5

Goodness of Fit Item FLU

\begin{tabular}{lcll}
\hline Criteria & Cut of Value & Result & Conclusion \\
\hline Chi-Square & $\leq 2 \mathrm{df}$ & 0,31 & Fit \\
P-Value & $\geq 0,05$ & 5 & Fit \\
RMSEA & $\leq 0,08$ & 0,000 & Fit \\
GFI & $\geq 0,90$ & 1,00 & Fit \\
AGFI & $\geq 0,90$ & 1,00 & Fit \\
NFI & $\geq 0,90$ & 1,00 & Fit \\
CFI & $\geq 0,95$ & 1,00 & Fit \\
IFI & $\geq 0,95$ & 1,01 & Fit \\
\hline
\end{tabular}

International Journal of Instruction, July $2019 \bullet$ Vol.12, No.3 
Table 5 shows the goodness of fit of the corresponding FLU item model. This means that this model is suitable and feasible to be used to measure the latent variable of fluency. This is also evidenced by the contribution value $\left(\mathrm{R}^{2}\right)$ in each item as shown in Table 6.

Table 6

Contribution Value $\left(\mathrm{R}^{2}\right)$

\begin{tabular}{ll}
\hline Item & $\mathrm{R}^{2}$ \\
\hline FLU1.1 & 0,32 \\
FLU1.2 & 0,35 \\
FLU1.3 & 0,42 \\
FLU2.4 & 0,40 \\
FLU2.5 & 0,45 \\
\hline
\end{tabular}

Table 6 shows that the contribution value $\left(\mathrm{R}^{2}\right)$ gives the largest contribution, which is $45 \%$ by FLU2.5.

\section{The Latent Variable of flexibility}

The latent variable of flexibility was measured based on 2 indicators with 5 items, i.e. 1) students complete (or justify) a question in one way, then they do it in another way from various questions (FLE1) with 3 items (FLE1.1-FLE1.3), 2) students are able to solve problems based on the number of different ways of relevant answers (FLE2) with 2 items (FLE2.4 - FLE2.5). For this reason, it is proven that the existing 5 items are unidimensional, meaning that they only measure the latent variable of flexibility.

The results of the CFA analysis of the variable of flexibility using the First Order Confirmatory Factor Analysis is shown in Figure 4 below.

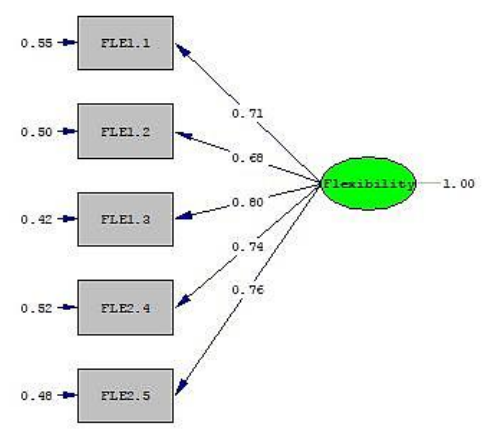

Chi-Square $=5.24, \mathrm{df}=5, \mathrm{P}$-value $=0.38714, \mathrm{RMSEA}=0.012$

Figure 4

Confirmatory Factor Analysis of Flexibility Variable

Based on the results of CFA analysis with the First Order Confirmatory Factor Analysis in Figure 4, the results obtained the fit model with Chi-Square $=5.24$, df $=5, \mathrm{P}$-value $=$ 
0.38714 (not significant), RMSEA $=0.012$. This means that by using one factor (unidimensional) all items only measure one single factor, FLE.

The proof of each item contributing significantly to the FLE variable was done by checking the T-Value of each loading factor coefficient as in Table 7 below.

Table 7

Loading Factor of FLE Items

\begin{tabular}{lllll}
\hline Item & Coefficient & Standard error & T-Value $(>1,96)$ & Criteria \\
\hline FLE1.1 & 0,71 & 0,55 & 13,05 & Significant \\
FLE1.2 & 0,68 & 0,50 & 12,99 & Significant \\
FLE1.3 & 0,80 & 0,42 & 15,20 & Significant \\
FLE2.4 & 0,74 & 0,52 & 13,65 & Significant \\
FLE2.5 & 0,76 & 0,48 & 14,18 & Significant \\
\hline
\end{tabular}

Table 7 shows the loading factor of all items that have a positive coefficient value and each item has T-Value> 1.96 so that it is concluded to be significant. Furthermore, the value of the variant-covariance matrix was tested by measuring the suitability of the Goodness of Fit model, as shown in Table 8.

Table 8

Goodness of Fit Item FLE

\begin{tabular}{lcll}
\hline Criteria & Cut of Value & Result & Conclusion \\
\hline Chi-Square & $\leq 2 \mathrm{df}$ & 5,24 & Fit \\
P-Value & $\geq 0,05$ & 0,3817 & Fit \\
RMSEA & $\leq 0,08$ & 0,012 & Fit \\
GFI & $\geq 0,90$ & 0,99 & Fit \\
AGFI & $\geq 0,90$ & 0,98 & Fit \\
NFI & $\geq 0,90$ & 0,99 & Fit \\
CFI & $\geq 0,95$ & 1,00 & Fit \\
IFI & $\geq 0,95$ & 1,00 & Fit \\
\hline
\end{tabular}

Table 8 shows the goodness of fit model of the FLE item accordingly. This means that this model is suitable and feasible to be used to measure the latent variable of flexibility. This is also evidenced by the contribution value $\left(\mathrm{R}^{2}\right)$ as presented in Table 9 .

Table 9

\begin{tabular}{|c|c|}
\hline \multicolumn{2}{|c|}{ Contribution Value $\left(\mathrm{R}^{2}\right)$} \\
\hline Item & $\mathrm{R}^{2}$ \\
\hline FLE1.1 & 0,23 \\
\hline FLE1.2 & 0,23 \\
\hline FLE1.3 & 0,37 \\
\hline FLE2.4 & 0,27 \\
\hline FLE2.5 & 0,30 \\
\hline
\end{tabular}

Table 9 shows that the contribution value $\left(\mathrm{R}^{2}\right)$ gives the largest contribution of $37 \%$ by FLE1.3. 


\section{The Latent Variable of Originality}

This latent variable was measured based on an indicator of students in examining various methods or answers and then compiling other solutions from the usual ones (ORI) with 5 items, (ORI1 - ORI5). For this reason, it is proven that the 5 items are unidimensional, meaning that they only measure the latent variable of originality.

The results of the CFA analysis of the latent variable of originality using the First Order Confirmatory Factor Analysis as shown in Figure 5 below.

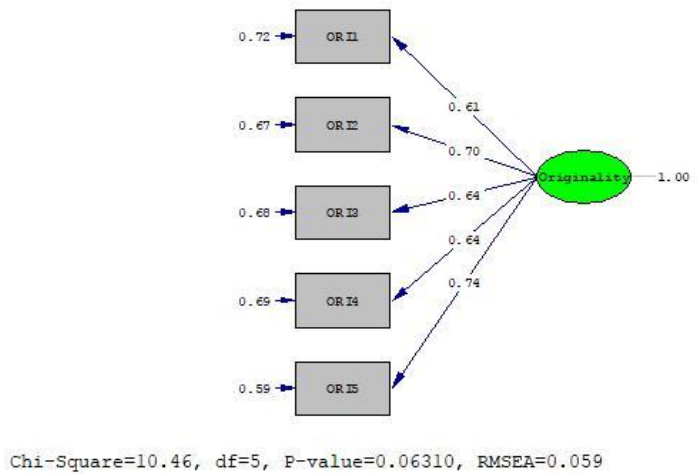

Figure 5

Confirmatory Factor Analysis of Originality Variable

Based on the results of CFA analysis of originality variables with the First Order Confirmatory Factor Analysis in Figure 5, the results obtained the fit model with ChiSquare $=10.46 \mathrm{df}=5, \mathrm{P}$-value $=0.06310$ (not significant), $\mathrm{RMSEA}=0.059$. This means that by using one factor (uni-dimensional) all items only measure one single factor, ORI.

The proof of each item contributing significantly to the ORI variable was done by checking the T-Value of each loading factor coefficient as in Table 10 below.

Table 10

Loading Factor of ORI Items

\begin{tabular}{lllll}
\hline Item & Coefficient & Standard error & T-Value $(>1,96)$ & Criteria \\
\hline ORI1.1 & 0,61 & 0,72 & 9,92 & Significant \\
ORI1.2 & 0,70 & 0,67 & 11,20 & Significant \\
ORI1.3 & 0,64 & 0,64 & 10,47 & Significant \\
ORI2.4 & 0,64 & 0,64 & 10,46 & Significant \\
ORI2.5 & 0,74 & 0,48 & 12,12 & Significant \\
\hline
\end{tabular}

Table 10 shows the loading factor of all items that have a positive coefficient value and each item has T-Value> 1.96 so that it is concluded to be significant. Furthermore, the value of the variant-covariance matrix was tested by measuring the suitability of the Goodness of Fit model, as shown in Table 11. 
Table 11

Goodness of Fit Item ORI

\begin{tabular}{llll}
\hline Criteria & Cut of Value & Result & Conclusion \\
\hline Chi-Square & $\leq 2 \mathrm{df}$ & 10,46 & Fit \\
P-Value & $\geq 0,05$ & 0,06310 & Fit \\
RMSEA & $\leq 0,08$ & 0,059 & Fit \\
GFI & $\geq 0,90$ & 0,99 & Fit \\
AGFI & $\geq 0,90$ & 0,96 & Fit \\
NFI & $\geq 0,90$ & 0,97 & Fit \\
CFI & $\geq 0,95$ & 0,98 & Fit \\
IFI & $\geq 0,95$ & 0,98 & Fit \\
\hline
\end{tabular}

Table 11 shows the goodness of fit model of the ORI item accordingly. This means that this model is suitable and feasible to be used to measure the latent variable of flexibility. This is also evidenced by the contribution value $\left(\mathrm{R}^{2}\right)$ as presented in Table 12 .

Table 12

Contribution Value $\left(\mathrm{R}^{2}\right)$

\begin{tabular}{ll}
\hline Item & $\mathrm{R}^{2}$ \\
\hline ORI1 & 0,12 \\
ORI2 & 0,18 \\
ORI3 & 0,14 \\
ORI4 & 0,14 \\
ORI5 & 0,23 \\
\hline
\end{tabular}

Table 9 shows that the contribution value $\left(\mathrm{R}^{2}\right)$ gives the largest contribution of $23 \%$ by ORI5.

\section{Second-Order Confirmatory Factor Analysis}

In the second CFA, the latent variable cannot be measured directly through the indicator variables. It has several indicators where the indicator cannot be measured directly and requires more indicators.

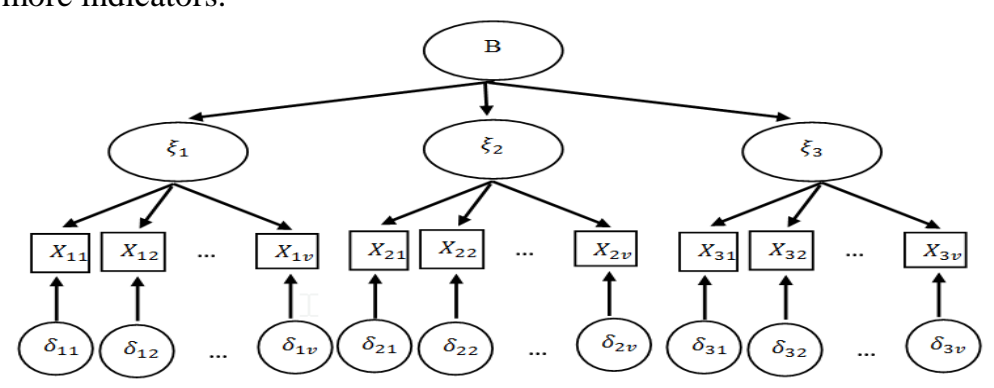

Figure 6

Second-order Confirmatory Factor Analysis Model

Based on the items obtained in each dimension in the first order analysis, the second order analysis of CFA was done. The use of Second-order confirmatory factor analysis 
in this study was to examine the mathematical creativity variable domain consisting of 3 indicators, fluency, flexibility, and originality. The results of the second-order confirmatory factor analysis of mathematical creativity variables are shown in Figure 7.

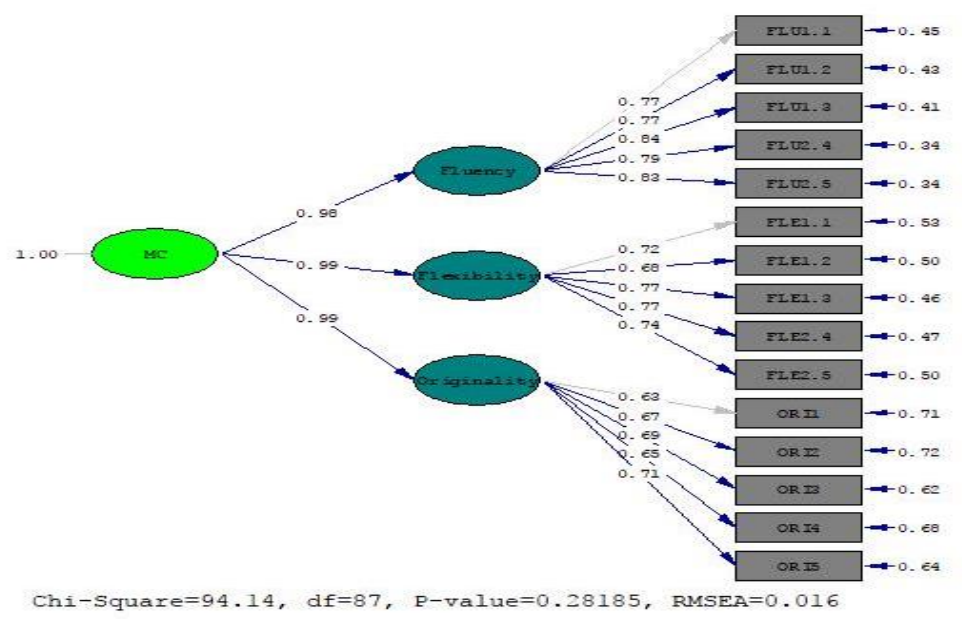

Figure 7

Path Diagram of Second-order Analysis Output

Based on the test results conducted with second-order confirmatory factor analysis on 15 items yielding p-value $=0.28185(\mathrm{p}>0.05)$ and RMSEA $=0.016($ RMSEA <0.05) Based on the data, p-value and RMSEA can be fulfilled so that it can be concluded that this model fit the data. The RMSEA 0.016 value indicates that the model is fit. In other words, it is uni-dimensional; all 15 items are valid indicators for measuring constructs of mathematical creativity.

The output of testing the value of the variant-covariance matrix with the measurement of the suitability of the Goodness of Fit model is shown in Table 13 below.

Table 13

Goodness of Fit

\begin{tabular}{llll}
\hline Criteria & Cut of Value & Result & Conclusion \\
\hline GFI & $\geq 0,90$ & 0,96 & Fit \\
AGFI & $\geq 0,90$ & 0,95 & Fit \\
NFI & $\geq 0,90$ & 0,96 & Fit \\
CFI & $\geq 0,95$ & 1,00 & Fit \\
IFI & $\geq 0,95$ & 1,00 & Fit \\
\hline
\end{tabular}

Based on the results in Table 13, it shows that the model is fit. This means that the 15 items can be used to measure latent mathematical creativity variables. It was concluded that mathematical creativity measurement instruments fulfill the assumption of unidimensionality. 
Table 14

Results of the Second Order CFA of the Mathematical Creativity Test

\begin{tabular}{lllll}
\hline Item & Loading factor & T-Value & $\mathrm{R}^{2}$ & Result \\
\hline Dimension: FLU & & & & \\
ItemFLU1.1 & 0,77 & - & 0,32 & Reference Item \\
ItemFLU1.2 & 0,77 & 13,94 & 0,34 & Item fit \\
ItemFLU1.3 & 0,64 & 14,67 & 0,41 & Item fit \\
ItemFLU2.4 & 0,79 & 14,82 & 0,42 & Item fit \\
ItemFLU2.5 & 0,82 & 15,10 & 0,45 & Item fit \\
Dimension: FLE & & & & \\
ItemFLE1.1 & 0,72 & - & 0,25 & Reference Item \\
ItemFLE1.2 & 0,68 & 11,70 & 0,23 & Item fit \\
ItemFLE1.3 & 0,77 & 12,67 & 0,32 & Item fit \\
ItemFLE2.4 & 0,77 & 12,56 & 0,31 & Item fit \\
ItemFLE2.5 & 0,74 & 12,23 & 0,28 & Item fit \\
Dimension: ORI & & & & \\
ItemORI1 & 0,63 & - & 0,13 & Reference Item \\
ItemORI2 & 0,67 & 9,18 & 0,14 & Item fit \\
ItemORI3 & 0,69 & 9,60 & 0,18 & Item fit \\
ItemORI4 & 0,65 & 9,22 & 0,15 & Item fit \\
ItemORI5 & 0,71 & 9,66 & 0,19 & Item fit \\
\hline
\end{tabular}

Based on Table 13, it can be explained that each item has a positive loading factor and each item T-Value> 1.96 is said to be significant. This means that all items are suitable for measuring mathematical creativity because the overall $\mathrm{t}$-value is greater than 1.96 . The contribution value $\left(\mathrm{R}^{2}\right)$ gives the largest contribution as much as $45 \%$ by FLU2.5 or can be seen based on the loading factor, the loading factor of 0.82 . While the ORI1 item gives the smallest contribution to loading factor 0.63 or contribution value $\left(\mathrm{R}^{2}\right)$ of $13 \%$.

\section{Mapping of Student Mathematical Creativity}

The level of students' mathematical creativity is obtained from the interpretation of scores obtained by the respondents in mathematical creativity test. The mathematical creativity test was followed by 313 junior high school students using 15 fit items. The students' scores obtained from the mathematical creativity instrument are raw scores, which need to be converted first to z-standard scores, with $\mu=0$, and $\sigma=1$. However, because the $\mathrm{z}$-standard score allows negative scores, then to make it easy for readability and interpretation, they need to be changed to t-score, with $\mu=50$, and $\sigma=10$. The results of the conversion scores through a simple MS Excel program, and which refers to categorization, as presented in the data analysis, show the mapping obtained from the mathematical creativity of junior high school students in Indonesia for each dimension as shown in Table 15. Meanwhile, the percentage of respondents in the level of mathematical creativity is shown in Figure 8. 
Table 15

Frequency Recapitulation of Mathematical Creativity Level for Each Dimension

\begin{tabular}{llll}
\hline Category & \multicolumn{3}{c}{ Dimension/factor } \\
\cline { 2 - 4 } & Fluency & Flexibility & Originality \\
\hline Low & 82 & 94 & 98 \\
Medium & 193 & 169 & 195 \\
High & 38 & 50 & 20 \\
\hline
\end{tabular}

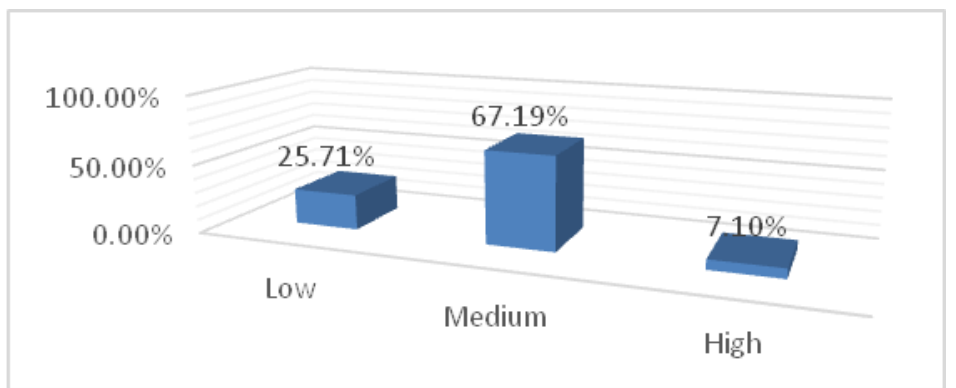

Figure 8

Graphic of Percentage of Students' Mathematical Creativity Level.

\section{DISCUSSION}

The procedures of construct validation start from identification and limitation regarding the mathematical creativity variable which will be measured and expressed in the form of the logical construct based on the mathematical creativity variable theory. If the results are in accordance with the expected model, the instrument is considered to have good construct validity (Retnawati, 2016).

The findings prove that the construct validity of the instrument of students' mathematical creativity using the first-order confirmatory factor analysis and secondorder confirmatory factor analysis approach indicates that the item is uni-dimensional. Uni-dimensional assumptions can only be shown if the test contains only one dominant component that measures the achievement of a subject (Retnawati et al., 2015). One component of the object measured in the instrument is mathematical creativity. There are 15 items in each dimension that measure mathematical creativity, where each item in each dimension is fit with the one-factor model and each item in each dimension contributes significantly.

Based on the previous studies, especially in Indonesia, it has been developed the mathematics creativity instruments for junior high school students, but the construct validation was not done, only content and appearance validation (Moma, 2015). The study developed an instrument to measure junior high school students' mathematical creativity, but to prove its validity, it only focused on content validity and the validity of the appearance by the expert team in terms of material to show valid instruments. Furthermore, these instruments were tested and analyzed quantitatively using product moment tests to measure item validity. The use of the product moment to measure item 
validity is incorrect. This is explained by (Kumaidi, 2004) that item-score correlation coefficients with total scores should not be interpreted as validity but as a discriminating power or part of item reliability. Based on this, the research on first-order and secondorder confirmatory factor analysis can be used as an improvement instrument before.

In addition, Pitta-Pantazi, Sophocleous, \& Christou (2013) also use variables of fluency, flexibility, and originality as mathematical variables of research creativity by investigating the relationship between mathematical creativity and cognitive styles. This is in accordance with the first-order and second-order confirmatory factor analysis research that mathematical creativity can be measured based on fluency, flexibility, and originality domains.

The existing studies are generally limited to the development of mathematical creativity instruments. The development of mathematical creativity instruments has been carried out, but it does not clearly describe the construct validity of mathematical creativity competency instruments in proving items in each dimension fit (according) to one-factor model in making a significant contribution, so these research findings differ from previous studies. As a research conducted by Kesumawati (2010) which focuses on construct validation done by the validator without field testing. Retnawati (2008) explains that construct validity can be done through field trials rather than through validators. The weakness of this research is the construct validity of mathematical creativity instrument is tested on junior high school students who come from high, medium and low school categories based on the national exam. Therefore, to get better results it is advisable to conduct experiments on a larger scale based on the entrance test score of junior high school so that those involved in testing are students who have certain categories. The use of students' ability categories based on the scores of the national exams enables different students' ability categories for testing.

\section{CONCLUSION}

The proof of construct validity of mathematical creativity instrument was based on three latent variables, fluency, flexibility, and originality. The instrument is composed of 15 items from the fluency, flexibility, and originality indicators which show that the loading factor has a significant effect as uni-dimensional on the latent variable on first-order and second-order confirmatory factor analysis; the T-Value at the loading factor value> 1,96. However, the limited number of items and the tight control of time allows the scores obtained by the respondents to be influential. The subjects testing which involves the categories based on national exams held by the Indonesian government rather than based on school entrance test scores also enables a bias categorization. Therefore, it would be better to take measurements by controlling time and involving the subjects testing based on the subject's initial ability.

Acknowledgment: This paper is funded by the Indonesian Educational Scholarship (LPDP). 


\section{REFERENCES}

Career Center Maine Department of Labor. (2004). Today's work competence in maine. Retrieved from http://www.maine.gov/labor/lmis/pdf/Essential WorkCompetencies.pdf.

Cho, S. (2003). Creative problem-solving in science: Divergent, convergent, or both? In U. Anuruthwong, \& C. Piboonchol (Eds.), Igniting children potentials and creativity. 7th Asia-Pacific Conference on Giftedness (pp. 169-174). Bangkok, Thailand: October Printing.

Cho, S. (2006). Developing creative problem-solving ability test for identification of the mathematically gifted. Paper presented at the 9th Asia-Pacific Conference on Gifted Education. Taipei, Taiwan.

Cohran, W. G. (2010). Sampling (Rusdiansya). New York, NY: John Wiley \& Sons.

Diakidoy, I.-A. N., \& Constantinou, C. P. (2001). Creativity in physics: Response Fluency and task specificity. Creativity Research Journal, 13(October 2014), 37-41. https://doi.org/10.1207/S15326934CRJ1334

Dogan, N. (2011). Creative thinking and creativity. In O. Demirel (Eds.), New trends in education. Ankara: Pegem Akademi Publication.

Florida, R., \& Cities, T. A. (2012). The Rise of the creative class , Revisited. National Journal's $A M \& P M$.

Grieshober, W. E. (2004). Continuing a dictionary of creativity terms \& definition. New York: International Center for Studies in Creativity State University of New York College at Buffalo. $\quad$ Retrieved from http://www.buffalostate.edu/orgs/cbir/ReadingRoom/theses/Grieswep.pdf.

Hair, J. F., Black, W. C., Babin, B. J., \& Anderson, R. E. (2006). Multivariate data analysis. Upper Saddle River, NJ: Prentice-Hall.

Hana, U. (2013). Competitive Advantage achievement through Innovation and Knowledge. Journal of Competitiveness, 52-96. https://doi.org/10.7441/joc.2013.01.06.

Heppell, S., Chapman, C., Millwood, R., Constable, M., \& Furness, J. (2004). Building Learning futures. A research Project at ultralab within the CABE/RIBA "Building Futures" programme. Retrieved from http://rubble.heppell.net/cabe/final_report.pdf.

Jaarsveld, S., \& Lachmann, T. (2017). Intelligence and creativity in problem solving: The Importance of test features in cognition research. Frontiers in Psychology, 8(February), 1-12. https://doi.org/10.3389/fpsyg.2017.00134.

Joreskog, K. G., \& Sorbom, D. (2003). Lisrel 8.54 help file. Chicago, IL: Scientific Software International.

Kattou, M., Kontoyianni, K., Pitta-Pantazi, D., \& Christou, C. (2011). Does Mathematical creativity differentiate mathematical ability? Paper presented at the 
CERME 7 - Seventh Congress of the European Society for Research in Mathematics Education. Rzeshów, Poland.

Kim, H., Cho, S., \& Ahn, D. (2003). Development of mathematical creative problemsolving ability test for identification of the gifted in math. Gifted Educational International, 18, 164-175.

Kind, P. M., \& Kind, V. (2007). Creativity in science education: Perspectives and challenges for developing studies in science education. Studies in Science Education, 43(1), 1-37. https://doi.org/10.1080/03057260708560225

Kumaidi. (2004). Interpretasi Koefisien Korelasi Skor-Butir dengan Skor Total Uji Kebermaknaan Koefisien Reliabilitas KR-20 dalam Penelitian Pendidikan dan Psikologi. Jurnal Ilmu Pendidikan, 11(2), 107-114.

Kesumawati, N. (2010). Development mathematical creative thinking ability problems on the topics of fractions for 7 grade students. In Zulkardi (Eds), The first South East Asia design/development research (SEA-DR) (pp.279-284). Unsri, Palembang.

Lin, C., \& Cho, S. (2011). Predicting Creative problem-solving in math from a dynamic system model of creative problem solving ability. Creativity Research Journal, 23(3), 255-261. https://doi.org/10.1080/10400419.2011.595986

Livne, N. L., Livne, O. E., \& Wight, C. A. (2008). Enhancing mathematical creativity through multiple solutions to open-ended problems online. Paper presented at the National Educational Computing Conference. Texas, USA.

Makmur, A. (2015). Efektivitas Penggunaan Metode BASE Method dalam Meningkatkan Kreativitas dan Motivasi Belajar Matematika Siswa SMP N 10 Padangsidimpuan. Jurnal EduTech, 1(1)

Mann, E. L. (2005). Mathematical Creativity and school mathematics: Indicators of Mathematical creativity in middle school students (Unpublished doctoral dissertation). Retrieved from https://opencommons.uconn.edu/dissertations/AAI3205573.

Martin. (2009). Convergent and divergent thinking. [Online Blog Article]. Retrieved from http://www.eruptingmind.com/convergent-divergent-creative-thinking/.

McGregor, D. (2007). Developing thinking developing learning. Poland: Open University Press.

Moma, L. (2015). Pengembangan Instrumen Kemampuan Berpikir Kreatif Matematis untuk Siswa SMP. Delta-Pi: Jurnal Matematika Dan Pendidikan Matematika, 4(1), 27 41.

Nadjafikhah, M., \& Yaftian, N. (2013). The Frontage of creativity and mathematical creativity. Procedia - Social and Behavioral Sciences, 90(InCULT 2012), 344-350. https://doi.org/10.1016/j.sbspro.2013.07.101

National Academies of Science. (2007). Rising above the gathering storm: Energizing and employing America for a brighter economic future. Washington, DC: National 
Academies Press.

Novitasari, D., Rahman, A., \& Alimuddin. (2015). Profil Kreativitas Siswa dalam Pemecahan Masalah Matematika Ditinjau dari Kecerdasan Visual Spasial dan Logis Matematis pada Siswa SMAN 3 Makassar. Jurnal Daya Matematis, 3, 41-50.

Pitta-Pantazi, D., Sophocleous, P., \& Christou, C. (2013). Spatial visualizers, object visualizers, and verbalizers: their mathematical creative abilities. ZDM, 45(2), 199-213.

Rahman, R. (2012). Hubungan antara self-concept terhadap matematika dengan kemampuan berpikir kreatif matematik siswa. Infinity, 1(1), 19-30.

Retnawati, H. (2008). Validitas dan reliabilitas konstruk skor tes kemampuan calon mahasiswa. Jurnal Ilmu Pendidikan, 23(2), 126-135.

Schoenfeld, A. H. (2015). Measures of problem-solving performance and of problemsolving instruction. National Council of Teachers of Mathematics, 13(1), 31-49.

Schoevers, E. M., Kroesbergen, E. H., \& Kattou, M. (2018). Mathematical creativity: A combination of domain-general creative and domain-specific mathematical skills. The Journal of Creative Behavior, 0, 1-11. https://doi.org/10.1002/jocb.361.

Sriraman, B. (2012). The elements of creativity and giftedness in bharath sriraman and the elements of creativity and giftedness in mathematics. The Netherlands: Sense Publisher.

Urban, K. (2003). Toward a componential model of creativity. In D. Ambrose, L. M. Cohen, \& A. J. Tannenbaum (Eds.), Creative intelligence: Toward theoretic integration (pp. 81-112). Cresskill, NJ: Hampton. 